\title{
Epictetus on Death
}

\section{Epiktetos’ta Ölüm Üzerine}

\section{Esra ÇAĞRI MUTLU*}

\begin{abstract}
The philosopher in Epictetus' Discourses is Socrates. Moreover, someone who reads Stoic philosophy over Epictetus, can think that the school Epictetus belonged is a Socratic school. The basic reason for this that there are some similarities between Socrates' and Stoics' ideas on death and the relationship of death to philosophy. Stoic philosophers especially take Socratic life as an example for Stoic life style. Socrates' ideas on self-control, his negligence on physical and emotional things affect them. Yet, there are some differences between their ideas. Socrates takes death as soul's escape from body and becoming free. Soul returns to its home and becomes immortal again by death and what gives this chance to it is philosophy and, in this manner, philosophy is a practice of death. When we return to Stoic philosophy firstly, we could see that they don't accept soul as an immortal entity like Socrates or Plato. On the contrary, they believe that the soul modifies itself. So, for Epictetus, unlike Plato's two-parted soul: rational and irrational, soul doesn't have two parts. Therefore, within this context we could see that Stoic philosophers accept death not as the escape of the soul nor something which we should be afraid of. According to them, death is a natural thing and so there is no point to be afraid of it. In this manner, I'll try to analyze the relationship of death to philosophy in Stoic philosophy, especially in Epictetus in this paper.
\end{abstract}

Key Words: Death, Volition, Freedom.

"No harm can come to the good man in life or in death, and his circumstances are not ignored by the gods" (Plato, Apology 41d).

Öz

Epiktetos'un Söylevler'indeki filozof Sokrates'tir. Dahası Epiktetos üzerinden Stoacı felsefeyi okuyan biri, Epiktetos'un ait olduğu okulun Sokratesçi bir okul olduğunu düşünebilir. Bunun temel nedeni, Sokrates ve Stoacıların ölüm, ölüm ve felsefe ilişkisi hakkındaki düşünceleri arasındaki benzerliklerdir. Stoacı filozoflar özellikle Stoacı yaşam tarzına örnek olarak Sokrates'in yaşamını ele alırlar. Sokrates'in kendini kontrol etme konusundaki düşünceleri, fiziksel ve duygusal şeylere dair ilgisizliği onları etkiler. Yine de Sokrates ve Stoacı okulun fikirleri arasında kimi farklılıklar da vardır. Sokrates ölümü, ruhun bedenden kaçması ve özgürleşmesi olarak alır. Ruh ölümle evine geri döner ve tekrar ölümsüz hale gelir ve ona bu şansı veren felsefedir; bu şekilde felsefe bir ölüm pratiğidir. Stoacı felsefeye döndüğümüzde ise ilk olarak onların Sokrates veya Platon gibi ruhu ölümsüz bir varlık olarak kabul etmediklerini görebiliriz. Aksine, ruhun kendisini değiştirdiğine inanırlar. Yani, Epiktetos için Platon'un iki kısımlı ruhunun aksine, rasyonel ve irrasyonel, ruhun iki kısmı yoktur. Bu nedenle Stoacı filozofların ölümü ne ruhun kaçışı olarak ne de korkmamız gereken bir şey olarak kabul ettiklerini görebiliriz. Onlara göre ölüm doğal bir şeydir ve ondan korkmak için bir sebep yoktur. Bu bağlamda makale Stoacı felsefede, özellikle de Epiktetos’ta ölüm ve felsefe ilişkisini analiz etmeye çalışacak.

Anahtar Kelimeler: Ölüm, Rasyonel Seçim, Özgürlük.

\section{Introduction}

Stoicism was founded in the third century BC by Zeno of Citium; Cleanthes succeeded him as the head of the school. But Chrysippus, the successor of Cleanthes, has the highest contribution to the development of Stoic doctrine and after him, Stoic philosophy has become dominant. It can be said that Stoicism is an integration of three tradition: the Socratic ethical tradition; the Heraclitean physical and materialistic tradition and dialectical tradition of the Megareans and of Aristotle. Besides this integration, Stoic life choice is always analogous to Socratic life choice (Hadot, 1998, p. 73).

Epictetus is one of the Stoic philosophers whom we could see this Socratic reflection very clearly. Epictetus as a member of Stoic school, is generally accepted as a later period Stoic philosopher, together with Seneca and M. Aurelius. As a later period Stoic philosopher Epictetus usually wrote on ethics. His works has come down to us by his pupil Arrian. His longest book is Discourses and beside that book we have a book of him called, "The

* Dr. Öğr. Üyesi Van Yüzüncü Yıl Üniversitesi, Edebiyat Fakültesi, Felsefe Bölümü, esramutlu@ @yu.edu.tr

Mutlu, E. Ç, (2018). Epiktetos’ta Ölüm Üzerine, Gaziantep University Journal of Social Sciences, 17 (4), $1262-$ 1269 Submission Date: 26-08-2018, Acceptance Date: 27-09-2018.

Araştırma Makalesi. 
Handbook" or "The Encheiridion". Epictetus usually has used Socrates as an example in these books, to teach his pupils that what disturb human-beings is not the things, but the judgments people have about those things (Dryden\&Still, 2012, p. 29). Epictetus thinks that it is always useful to remember Socrates, what he did and said in every situation (Erler, 2007, p. 99).

Now the later period Stoics have divided philosophy into three main disciplines: logic, physics (metaphysics) and ethics. Logic has usually been about the method of the right knowledge, and what were the boundaries of our knowledge. Physics has tried to solve the problems regarding the structure of the universe and the natural laws. Finally, ethics was concerned about the meaning of human-being's life, and what was his/her attitude towards life and death. Within this division, logic and metaphysics were generally perceived only as an introduction to ethics so, ethics has accepted as the crown jewel of sciences. Therefore, as Long has emphasized, when we take Epictetus' philosophy within this distinction, we will see that there are four main concepts by which we could analyze Epictetus' philosophy as a whole. These concepts can be sorted as freedom, judgement, volition (prohairesis) and integrity (Long, 2002, p. 26). Especially volition is the main concept which Epictetus has dwelled on. For he believes that by volition you can face everything in your life calmly and without having any fear and one of these fears which human-beings are usually experienced is the fear of death.

Before analyzing these concepts first, we have to say something about the titles of Epictetus' books. The Handbook or "The Encheiridion" is accepted as the soul of Stoic philosophy by Justus Lipsius (Sellars, 2009, p. 129). Its Greek title means both "always ready at hand" and "sword". Sellars says that according to Simplicius, Epictetus has chosen this title on purpose. For he wants a philosophical guide or manual for his pupils:

It is called Encheiridion because all persons who are desirous to live as they ought, should be perfect in this book, and have it always ready at hand (prokheiron); a book of as constant and necessary use as the sword (which commonly went by this name, and from whence the metaphor seems to be taken) is to a soldier (Sellars, 2009, p. 130).

Now the title of the book indicates all things ready to hand so the book could be a guidebook or manual for using in conducting practical activity. Every chapter can be accepted as presenting practical advices rather than substantial philosophical arguments (Sellars, 2009, s. 130-131). The main theme of the book is about the division of the things we can have or see or experience in our daily lives. Epictetus, with following Socratic account on the possessions, divide things into two parts:

Some things are up to us and some are not up to us. Our opinions are up to us, and our impulses, desires, aversions - in short, whatever is our own doing. Our bodies are not up to us, nor are our possessions, our reputations, or our public offices, or, that is, whatever is not our own doing. The things that are up to us are by nature free, unhindered, und unimpeded; the things that are not up to us are weak, enslaved, hindered, not our own (Epictetus, 1983, I.1).

\section{Four Main Concepts}

As we have said before Epictetus has four main concepts and within this division of things above, the first concept we should look for is "freedom". The first concept, freedom, is understood from a psychological point by Epictetus. He thinks that to be free means not be impeded by any external circumstances or emotional reactions:

... Freedom, you see, is having events go in accordance with our will, never contrary to it (Epictetus, 2008, I.12).

Free is the person who lives as he wishes and cannot be coerced, impeded or compelled, whose impulses cannot be thwarted, who always gets what he desires and never should experience what he would rather avoid (Epictetus, 2008, IV.1.1). 
Because of being a liberated slave, Epictetus has usually referred to the importance of being free and he says that the most important freedom a human-being has, is to think or to actualize his capacity of thinking without being derailed by some obstacles:

What is it then that renders a person free and independent? Money is not the answer, nor is a governorship, a consulship, or even a kingdom. Something else needs to be found. Well, what makes for freedom and fluency in the practice of writing? Knowledge of how to write. The same goes for the practice of playing an instrument. It follows that, in the conduct of life, there must be a science to living well (Epictetus, 2008, IV.1. 62).

For Epictetus, the science of living well is ethics and by ethics you could learn the general rules and how you can apply these rules to particular cases. Ethics teaches you that there are things which are under your control, and things which are not under your control. In life, not everything is under your control so if you accept everything as they are, then you won't feel restricted or restrained:

... Take someone in want of something under the control of people other than himself; is it possible for him to be unrestricted or unrestrained?

'No.'

Consequently, he cannot be free either. Now consider: is there nothing that is under our control, is everything under our control - or are there some things we control, and others that we don't?

... "Well, then, answer me something else: do you think freedom is grand and glorious, a thing of some significance?

'Of course.'

And can anyone be possessed of something so grand, glorious and important feel inferior?

'Impossible.'

... And do you think of freedom as something autonomous and self-sufficient?

'Yes.'

Then whoever is liable to be hindered or compelled by someone else is assuredly not free (Epictetus, 2008, IV.1.52-57).

In this regard, a human-being who has learned to discriminate between what belongs to him/her and what doesn't, will no longer be frightened of the things which do not belong to him/her on his/her own. For no one will have power on those things, but on him/her and death is one of these things which are not in our power:

... because what would you fear them for? Not the things that are your own, that constitute the essence of what is good and bad, because no one has power over them but you (Epictetus, 2008, IV.1.82).

Being free from those things such as death, emotions, bodily conditions make people more thoughtful and have better judgments over facts about nature and themselves and "having better judgments" is the second main concept of Epictetus. Epictetus believes that all mental states can be accepted as conditioned by judgments:

What upsets people is not things themselves but their judgments about the things. For example, death is nothing dreadful (or else it would have appeared dreadful to Socrates), but instead the judgment about death that it is dreadful - that is what is dreadful. So, when we are thwarted or upset or distressed, let us never blame someone else but rather ourselves, that is, our own judgments. An uneducated person accuses others when he is doing badly; a partly educated person accuses himself, an educated person accuses neither someone else nor himself (Epictetus, 1983, V).

As we can see for Epictetus, what disturbs us about anything is not the thing, rather the judgments we've developed about it or how we define it. For when we define something as bad or good, i.e. even it is neutral in itself, we make evaluative judgements towards it. One of Epictetus' example for such a judgment is our judgements about death; for him death is a 
merely natural thing but our judgements about it makes it fearful or bad. To not hold fears against death we must see that nothing is bad, good, dreadful etc. in itself and to have such a character brings us to Epictetus' third and maybe the most important concept; "volition".

... Look for it in your volition, friend - that is, in your desire and avoidance. Make it your goal never to fail in your desires or experience things you would rather avoid; try never to err in impulse and repulsion; aim to be perfect also in the practice of attention and withholding judgement (Epictetus, 2008, I.4.11).

Volition or will or choice, both are the English translations of Greek word prohairesis, which is also very important for Aristotle. We see that prohairesis, among Stoics, is practically unique to Epictetus and for him possessing free choice differs us from all animals; all animals are subject to impressions, but human beings differ by possessing the power of language and thinking (logos) and by this power they can have unconfined and independent choice:

... Who are you? In the first place, a human being, which is to say, a being possessed of no greater faculty than free choice, with all your other faculties subordinate to it, choice itself being unconfined and independent. Next, consider the gift of reason: it sets you apart from wild animals; it sets you apart from sheep. By virtue of these two faculties you are a member of the universe with full citizen rights; you were born not to serve but to govern, because you understand the divine order and its pattern (Epictetus, 2008, II.10.1-3).

The difference between impressions and judgments is that the first ones are not in our control, but our judgments are always in our control. According to Epictetus, the way things appear to human-beings are not subject to one's wishes, but their judgments are always voluntary. Because of impressions sometimes our judgments have been unconsidered, and this prevent our capacity of thinking from functioning. Whereas the capacity of thinking is the essential faculty of human-beings and by this capacity we have the power to understand the use of impressions. To eat, drink, rest, procreate are not enough for us as they are enough for animals. However, by our thinking capacity we can also understand cosmos and our place in it. So, it is not enough to have this capacity but also, we ought to realize it. Nature needs us all to realize our capacities (dunameis), for each of us should play our roles (Johnson, 2014, p. 30). Yet our essential selves for Epictetus are our volitions and by our volitions we'll have a chance to be free. To be free also means not to identify ourselves with impressions or with external things such as political powers, other people. If we pursue these external things we will never be free (Long, 2002, p. 29).

... All right then, let us go over the points we are agreed on. The unhindered person is free, that is, the person who has ready access to things in the condition he prefers. Whoever can be thwarted, however, or coerced, frustrated or forced into a situation against their will - that person is a slave. The person who renounces externals cannot be hindered, as externals are things that are not within our power either to have or not to have - or to have in the condition we might like. Externals include the body and its members, as well as material goods. If you grow attached to any of them as if they were your own, you will incur the penalties prescribed for a thief (Epictetus, 2008, IV.1.128-130).

These external things which have secondary values are different from the internal goods of moral excellence and to preserve your moral excellence against them brings the fourth concept, "integrity" into game. For with integrity Epictetus thinks that we can both honor our roles and our relation to others. Having a good volition entails uncompromising integrity (Long, 2002, p. 30).

Now within these explanations regarding Epictetus' four concepts, we have a position for having an idea about death. As we've seen Epictetus takes death not as a dreadful thing in itself rather he wants to talk about the judgments we had towards it. In general, Stoic philosophers have named death, weakness, health, beauty, ugliness, pleasure, pain not as goods or evils but rather indifferents (adiaphora) and within those they see death with 
weakness, illness, poverty as dispreferred (apoproegmena) indifferents (Stephens, 2014, p. 365).

They [the Stoics] say that some existing things are good, others are bad and others are neither of these.

(2) The virtues — prudence, justice, courage, moderation and the rest — are good. (3) The opposites of these foolishness, injustice and the rest - are bad. (4) Everything which neither does benefit nor harms is neither of these: for instance, life, health] pleasure, beauty, strength, wealth, reputation, noble birth, and them opposites, death, disease, pain, ugliness, weakness, poverty, low repute ignoble birth and the like... For these things are not good but indifferents of the species 'preferred', (5) For just as heating, not chilling is the peculiar characteristic of what is hot, so too benefiting, not harming is the peculiar characteristic of what is good. But wealth and health no more do benefit than they harm. Therefore, wealth and health are not something good. (6) Furthermore, they say: that which can be used well and badly is not something good. But wealth and health can be used well and badly. Therefore, wealth and health are not something good (Long, Sedley, 1987, p. 354, Diogenes Laertius 7.101-3).

By naming death as a "dispreferred indifferent" all Epictetus wants to do is to controvert the fear of death. Stephens thinks that to reach this goal, Epictetus approves eight assertions: 1. If you have a cosmic perspective on death then you can have an essential knowledge on why death is an indifferent, 2. If you could overcome your fear of mortality then you can survive, 3. You can be justified if you want to exit life (suicide), 4. Living or dying is up to you i.e. these are your personal autonomous decisions, 5. You have a particular body and soul and you have to know that neither of them will survive death, 6 . If you preserve your knowledge regarding that you are a mortal like all your loved ones then you can take comfort with your life, 7 . To have a thinking capacity which differentiates you from all animals frees you from the fear of death, 8. Death is not good or dreadful in itself but your judgments about it detracts you from living a virtuous life (Stephens, 2014, p. 366).

With the help of these eight assertions we can have an integrative view on death. First of all, what we should do is to accept that we are mortal beings and one day we will die:

... What is death? A scary mask [bugbear]. Take it off - see, it doesn't bite. Eventually, body and soul will have to separate, just as they existed separately before we were born. So why be upset if it happens now? If it isn't now, it's later. And why now, if that happens to be the case? To accommodate the world's cycle; because the world needs things to come into being now, things to come into being later and it needs things whose time is now complete (Epictetus, 2008, II.1.17-18).

According to Erler, accepting death as a bugbear is a reference to Socrates, or Plato's Phaedo. For in Phaedo, Socrates warns others for not letting the child inside man be frightened by "bugbears" like death (Erler, 2007, s. 99). Epictetus says that the way to defend ourselves against those bugbears is doing everything both cautiously (eulabos) and confidently (tharrountos):

... where the things that lie outside the province of the moral purpose are involved, there show confidence, but where the things that lie within the province of the moral purpose are involved, there show caution (Epictetus, 1956, II.1.5.).

Epictetus says that person who is afraid of death is the one who has confused objects of fear with objects of confidence. Because of they are afraid of death, in fact it is outside the providence of their moral purpose. Whereas they are confident about the things which are inside the providence of their moral purpose and by this they mix up the objects of caution and confidence. However;

... Your duty is to prepare for death and imprisonment, torture and exile - and all such evils - with confidence, because you have faith in the one who has called on you to face them, having judged you worthy of the role. When you take on the role, you will show the superiority of reason and the mind over forces unconnected with the will. Then that paradox will no longer seem so paradoxical or absurd that we should be confident and cautious at the same time: confident in relation to things outside the will, cautious about things within (Epictetus, 2008, II.1. 39-40). 
This idea is similar to Socrates' ideas on death in Phaedo. For Socrates says that because of the lack of experience and education adults are affected by things such as death as they are children. Whereas with education they will get the certain educations to avoid the child within their selves. With education, you learn to turn the scary mask and learn what is really is. So, "death as a bugbear; a child within man, who needs to be well educated in order to turn the bugbear around and to see what it really is: something which is not in our power and is therefore morally indifferent". Socrates' presupposes - or so Epictetus suggests - what is the basic tenet of Epictetus' ethics: "to judge what is in our power and what is not." (Erler, 2007, p. 99).

On the other hand, although there are similarities between Epictetus and Socrates' ideas regarding death, we should not to forget that Epictetus, unlike Socrates or Plato, treats soul as a mortal thing like body. For he thinks that with death your body and soul separates from each other, but this doesn't mean annihilation, rather change. The death of someone is natural and means the transformation of the elements which constitute body and soul into different elements:

\footnotetext{
... "But it is now time to die." Why say "die"? Make no tragic parade of the matter but speak of it as it is: "It is now time for the material of which you are constituted to be restored to those elements from which it came." And what is there terrible about that? What one of the things that make up the universe will be lost, what novel or unreasonable thing will have taken place? Is it for this that the tyrant inspires fear? (Epictetus, 1959, IV.7.15).
}

For Epictetus death is a change of that which is now, not into what is not, but into what is not now (III.24.93). This means that within cosmic cycle, to maintain this cycle, we should embrace that the material elements of the cosmos are recycling and as long as having a whole of body and soul we are also parts of this recycling. Therefore, death is as inevitable, predictable and ordinary as birth, decay and rebirth throughout nature (Stephens, 2014, p. $368)$.

Now if death is as ordinary as birth then there is no excuse for us to have a fear of being mortal. For every living being must die and, in this way, the cosmic cycle could proceed. As Stephens has emphasized, "whatever in you was fire returns to fire, whatever was of earth returns to earth, whatever was of pneuma returns to pneuma, whatever was of water returns to water." (Stephens, 2014, p. 385).

On the other hand, by accepting that you are a mortal being, this follows that all others are mortal beings which including your loved ones. So, there is no point to mourn after their death or to wish them to live forever. This wish also means to wish them to be not human beings or to wish them to be gods for only gods can be immortals. Now it is easy to see how this idea will sound foolish for Epictetus:

You are foolish if you want your children and your wife and your friends to live forever, since you are wanting things to be up to you that are not up to you, and things to be yours that are not yours. You are stupid in the same way if you want your slave boy to be faultless, since you are wanting badness not to be badness but something else. But wanting not to fail to get what you desire - this you are capable of. A person's master is someone who has power over what he wants or does not want, either to obtain it or take it away. Whoever wants to be free, therefore, let him not want or avoid anything that is up to others. Otherwise he will necessarily be a slave (Epictetus, 1983, 14).

When a loved one is dead, Epictetus advices us not to mourn after him/her rather to celebrate the life you've shared with him/her. All persons can be accepted as the temporary loans from the cosmos (Stephens, 2014, 370).

Never say about anything, "I have lost it," but instead, "I have given it back." Did your child die? It was given back. Did your wife die? She was given back. "My land was taken." So, this too was given back. "But the person who took it was bad!" How does the way the giver asked for it back concern you? As 
long as he gives it, take care of it as something that is not your own, just as travelers treat an inn (Epictetus, 1983, 11).

We are transients in cosmos, so cosmos is like a temporary home for all the mortal beings and it is possible for us to leave this home before the time has come. As we've seen in number 3 and 4; you can be justified if you want to exit life (suicide) and living or dying is up to you i.e. these are your personal autonomous decisions, Epictetus lives an open door to suicide. There are some conditions to go out through this door, though. According to Bonnhöffer, Epictetus thinks a suicide "is immoral when it is reckless, without rational consideration of all reasons for and against, when it results from passion, softness or cowardice or is the result of thoughtlessness, obstinacy, a vain thirst for glory, or disregard of one's social duties", also death must be seen as something to be spurned, and suicide something to be sought in specific contexts (Bonnhöffer, 1996, 61, 65, 66). We can accept the suicide moral as long as it is based on god's call.

\section{Conclusion}

As a result, for Epictetus there is no need to be afraid of death or how you will die. For him the process of dying won't change anything for all men must die and all the roads bring you to this conclusion are equal:

\footnotetext{
Very well, what further concern have I? For my part has been fulfilled. The business belongs to someone else, that is, the helmsman. But, more than that, the ship goes down. What, then, have I to do? What I can; that is the only thing I do; I drown without fear, neither shrieking nor crying out against God, but recognizing that what is born must also perish. For I am not eternal, but a man; a part of the whole, as an hour is part of a day. I must come on as the hour and like an hour pass away. What difference, then, is it to me how I pass away, whether by drowning or by a fever? For by something of the sort I must needs pass away (Epictetus, 1956, II.5.13-14).
}

For Epictetus, there is no good or bad death; what is good or bad is our judgments about it. Therefore, death is only the separation of body from soul. However, we should emphasize that within this separation Epictetus doesn't believe in the immortality of soul, unlike Socrates. He believes that with death, both body and soul will not perish but rather transform to anything in the cosmic cycle and if the cosmic cycle proceeds, death will be accepted as natural, inevitable as birth. We should be confident towards death and our caution should focus on that we have a false judgment about death and that is why we see death as a fearful thing. When you've freed yourself from the dreadful, false judgments by the help of your capacity of thinking then you can say that "I'm a free person" and to be able to say this, is the main goal of Epictetus.

\section{References}

Bonnhöffer, A. (1996). The ethics of the stoic Epictetus: an english translation. (W.O. Stephens, Trans.). NY: Peter Lang.

Dryden, W., Still, A. (2012). The historical and philosophical context of rational psychotherapy: the legacy of Epictetus. London: Karnac Pub.

Epictetus (1956). The discourses as reported by Arrian, the manual, and fragments. (W. A.

Oldfather, Trans.). Loeb Vol. I, Harvard: Harvard University Press.

Epictetus (1959). The discourses as reported by Arrian, the Manual, and fragments. (W. A. Oldfather, Trans.). Loeb Vol. II, Harvard: Harvard University Press.

Epictetus (1983). The handbook (the encheiridion). (N. P. White, Trans.). Indianapolis: Hackett Publishing Company.

Epictetus (2008). Discourses and selected writings. (R. Dobbins, Trans.). NY: Penguin Books. 
Erler, M. (2007). Death is a bugbear: socratic 'epode' and Epictetus' philosophy of the self, Scaltas, T. (Ed.). the philosophy of Epictetus. pp. 99-111. Oxford: Oxford University Press.

Hadot, P. (1998). The inner citadel. London: Harvard University Press.

Johnson, B. E. (2014). Socrates, Heracles, and the deflation of roles in Epictetus. D. R. Gordon, D. B. Suits (Eds.), Epictetus: his continuing influence and contemporary relevance. pp. 15-40. NY: Rit Press.

Long, A. A., Sedley, D. (1987). The hellenistic philosophers, translations of the principal sources with philosophical commentary, vol. I. Cambridge: Cambridge University Press.

Long, A. A. (2002). Epictetus: a stoic and socratic guide to life. Oxford: Clarendon Press.

Long, A.A. (2004). The socratic imprint on Epictetus' philosophy. S.K. Strange, J. Zupko (Eds.), stoicism: traditions and transformations. pp. 10-31. Cambridge: Cambridge University Press.

Sellars, J. (2009). The art of living: the stoics on the nature and function of philosophy. London: Bloomsbury.

Stephens, W.O. (2014), Epictetus on fearing death: bugbear and open door policy. Ancient hilosophy, 34, 365-391. 